\title{
Impact of Acidified Hydrogen peroxide on Dissolution Behaviour of Anka Complex Sulphide Mineral for Advanced Materials Application
}

\author{
Ola-omole, O. O and Nheta, W.
}

\begin{abstract}
The effects of acidified hydrogen peroxide on dissolution behaviour of a complex sulphide mineral for advanced materials application was investigated. Mineral sample was comminuted and sieved into several particle sizes ranges using the $\sqrt{2}$ method to select successive sieves. The mineral sample was characterized with ICP-OES, SEM and XRD. Electrochemical studies were carried out using open circuit potential, potentiodynamic polarization and Chronoamperometric methods. $1 \mathrm{M}$ each of $\mathrm{HCl}$ and $\mathrm{HNO}_{3}$ were added to varying molarities of $\mathrm{H}_{2} \mathrm{O}_{2}$ as the electrolyte. Results show that the ore comprises of galena, anglesite, sphalerite, copper, magnetite, arsenic and quartz. Addition of $\mathrm{H}_{2} \mathrm{O}_{2}$ at varying molarity produced effects on the reactivity of the mineral in the electrolyte. Potentiodynamic polarization curves show that behaviour of the ore with $\mathrm{HCl}$ and $\mathrm{HNO}_{3}+\mathrm{H}_{2} \mathrm{O}_{2}$ were similar in the sense that dissolution potentials shifted negatively as concentration of $\mathrm{H}_{2} \mathrm{O}_{2}$ increases from $0.25 \mathrm{M}$ to $1 \mathrm{M}$. Chronoamperometric behaviour of the ore show that dissolution kinetics decrease with increase in time up to 7200 seconds for the various applied potentials. Dissolution data obtained from electrochemical tests show that the presence of hydrogen peroxide enhance dissolution with $\mathrm{HCl}$ and $\mathrm{HNO}_{3}$; dissolution rates increase with increase in molarity of $\mathrm{H}_{2} \mathrm{O}_{2}$ (up to $1 \mathrm{M}$ ) plus $1 \mathrm{M} \mathrm{HCl}$ and $\mathrm{HNO}_{3}$. Highest dissolution rate of $1.066+00 \mathrm{~mm} / \mathrm{yr}$ was obtained from $\mathrm{HNO}_{3}$ plus I $\mathrm{M} \mathrm{H}_{2} \mathrm{O}_{2}$. It was ascertained that $\mathrm{HNO}_{3}$ $+\mathrm{H}_{2} \mathrm{O}_{2}$ has higher tendency to dissolve Anka sulphide mineral than $\mathrm{HCl}+\mathrm{H}_{2} \mathrm{O}_{2}$.
\end{abstract}

Keywords: Advanced Materials, Electrochemical behaviour, Extraction, Sulphide minerals.

\section{INTRODUCTION}

Metallic ore grades are falling globally as the higher grade reserve are exploited first and are progressively depleted [1]. The demand for base metals throughout the world increases on daily basis, the reason is not far fetch from the fact that metals are highly useful as they are the backbone of all engineering projects and products. Their uses vary from primitive tools of agriculture to advance aircrafts, automobiles, building and bridge construction, railways, light and heavy machinery and equipment shipping and transportation. Complex ores by their

Manuscript received October 7, 2020.

O. O. Ola-omole, is with Mineral Processing Research and Technology center Metallurgy Department, University of Johannesburg, South Africa.

W. Nheta, is with Mineral processing research and Technology center Metallurgy Department, University of Johannesburg, South Africa. nature are highly difficult to process because of the complication in their mineralogical associations. These complexities usually result in incomplete understanding of the dissolution behaviour of the associated minerals. This will also result in incomplete understanding of criteria for effective extraction and thereby leading to waste of resources expended in the metal extraction process. Effective extraction also becomes more difficult to achieve.

The dissolution of sulphide and oxide minerals is important in a wide range of fields, including hydrometallurgy, geochemistry and materials science. This is because most of the valuable metals processed in metallurgical operations are present as minerals of sulphides and oxides [2]. In recent times, electrochemical methods have been used to measure dissolution rates of ores and minerals because they can measure low dissolution rates. These methods involve the active and passive experiments and the three variables involved are potential (E), current (I) and time (t). Rao and Chernyshova [3], stated that many fundamental issues especially related to sulphide mineral water interface are still unresolved and poorly understood. It was reported that no general theory of redox chemistry of the sulphide ore in water in spite of all studies and experiment done by several authors. In order to modify the redox reaction of mineral surfaces as a tool for providing adsorption selectivity, there is need to know the oxidizing and reducing criteria of the ore. There is need to also know the adsorption forms of ubiquitous in geochemical system and how does introduction of $\mathrm{S}^{2}-, \mathrm{CN}-, \mathrm{O}_{2}$ and $\mathrm{H}_{2} \mathrm{O}_{2}$ adsorption influence before this picture.

Electrochemical behaviour of sulphide minerals has been largely studied $[4 ; 5 ; 6 ; 7 ; 8]$. These metals have received more attention after being recognized as valuable deposits of nonferrous metals. The electrochemistry study of sulphide minerals has been reviewed and most of the work aimed at understanding their behaviour in different stages of mineral processing, particularly in the leaching stage. These electrochemical processes, which are determined by the electrochemical interactions on dissolution at the electrode surface, are dependent on the composition and morphology of the mineral [9]. Surface species found on galena during oxidation and dissolution have been studied using many techniques [10]. It has been assumed that complexation takes place at the surface of hydrous galena sulphide. The adsorption of $\mathrm{H}+$ ions onto a surface of the $\mathrm{S}$ atom in the aqueous phase is 
found to be favourable, whereas the adsorption unto the surface of $\mathrm{Pb}$ atom is not favourable as suggested by [11].

According to $[12 ; 13]$ the kinetics of dissolution of sulphide minerals in chloride media has received considerable attention recently and there are several justifications for this interest. Among them is the availability of materials for construction with improved resistance to chloride attack. Most importantly, however, is the substantially faster dissolution rate exhibited by sulphides in chloride media, as well as the potential application of such electrolytes in the treatment of complex sulphide ores [14]. Hydrogen peroxide has the possibility of aiding oxidation or dissolution kinetics [15]. It is a strong oxidizing agent and promotes the oxidation and leaching potential in acid leaching. Besides its high oxidizing potential, it is easier to handle than gaseous oxidants. Therefore, hydrogen peroxide is the oxidant engaged in the dissolution process of Anka sulphide minerals in this study.

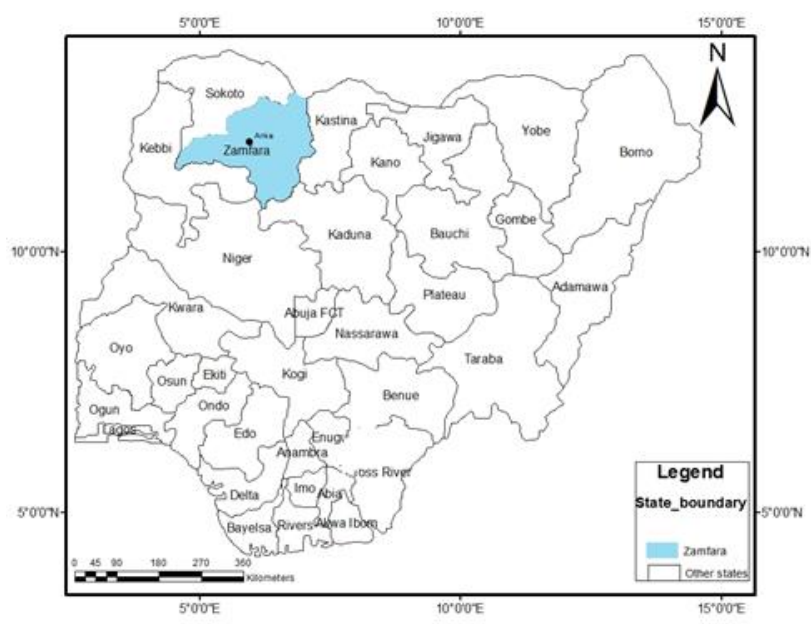

Fig. 1. Map of Nigeria showing the location of the study area.

The study area covers about $990 \mathrm{~km}^{2}$ is Anka local government is located between longitude $505^{\prime}$ ' E and $6008^{\prime} \mathrm{E}$ and latitude $11051^{\prime} \mathrm{N}$ and $12008^{\prime} \mathrm{N}$ in the Zamfara state North-Western part of Nigeria (Fig. 1). The area is characterized by generally gentle relief. Geologically, Anka is the schist belt of the Nigerian basement complex which is part of the Pan African mobile belt, sandwiched between the West African craton and the Congo Craton [16]. The area has a main surface water body which lies about a kilometer to the North of the town and numerous seasonal streams dissects. The deposit is yet to be exploited for advanced material applications though a few authors have studied the mineralization and exploration. In Vitro Bio-accessibility of Lead in Artisanal Mining Contaminated Soils and Sediments from the Area has also been studied [16].This is therefore, the thrust for this work to study the processing this mineral for the purpose of advanced materials applications using the electrochemical mechanism. Anka deposit is yet to be exploited for advanced material applications though a few authors have studied the mineralization and exploration. This is therefore, the thrust for this work to study the processing this mineral for the purpose of advanced materials applications using the electrochemical mechanism.

\section{Procedure}

\section{A. Sample sourcing and characterization}

The sulphide mineral ore used for this study was sourced from Anka North West (50 5' E and $6008^{\prime} \mathrm{E}$ and $11051^{\prime} \mathrm{N}$ and 120 08'E) Nigeria. It was routed through a closed circuit, crushing and sieving, to obtain particle size fractions +150 , 106,75 and $53 \mu \mathrm{m}$ using the $\sqrt{2}$ method to select successive sieves. Representative of each of the particle size was taken for mineralogical analysis to determine liberation size of the mineral. Mineralogical characterization of the sample was carried out using a combination of Scanning Electron Microscopy combined with Energy Dispersive X-ray analysis (SEM/EDX) and X-ray Diffractometry, (XRD). Elemental composition of the deposit was determined with ICP-OES.

\section{B. Electrochemical Studies}

Electrochemical tests were carried out on the mineral sample using open circuit potential (OCP), potentiodynamic polarization, and chronoamperometry techniques according to ASTM-G3--14. A conventional three electrode system electrochemical cell comprising the working electrode made from the ores, graphite rods counter electrode, and a silver/silver chloride, reference electrode was used. A potentiostat (VERSASTAT4) was used for the electrochemical measurements. The general purpose electrochemical software (GPES) version 4.9 was used for the analyses of the results.

The working electrodes were prepared from pulverized samples of the ores. The ore was mixed with graphite powder and silicon oil in ratio 1.5:1:1.75 as recommended by [8; 6; 17]. The graphite was added to improve the conductivity of the working electrode whilst the silicon oil served as a binder. The mixture was then compressed under pressure inside a carbon paste electrode holder while metal bolt was used to connect copper wire with the electrode. The working electrodes were prepared a day before conducting electrochemical experiments to give the samples enough time to dry. The electrochemical cell was made of a $1000 \mathrm{ml}$ Pyrex glass beaker suitable for a conventional three-electrode system, the reference electrode, working electrode, counter electrode. The electrolyte used for the electrochemical measurements was $1 \mathrm{M}$ of $\mathrm{HCl}$ and $\mathrm{HNO}_{3}$ with addition of $\mathrm{H}_{2} \mathrm{O}_{2}$ separately as oxidant at varying concentrations of $0.25,0.5,0.75$, and $1 \mathrm{M}$ respectively. The working electrode were subjected to the electrolyte at room temperature $\left(25^{\circ} \pm 1^{\circ} \mathrm{C}\right)$.

Potentiodynamic polarization measurements were conducted at scan rate of $0.2001 \mathrm{mV} / \mathrm{s}$ starting from -0.5 to $1.5 \mathrm{~V}$ versus the reference electrode. After each scan, the electrolytes were replaced with fresh electrolyte. Chronoamperometric behaviour was measured for 7200 seconds under four different applied potentials $(0.6,0.8,1.0$ and $1.2 \mathrm{~V})$ at anodic part of the potentiodynamic polarization curves. Electrochemical interface was connected to a personal computer with application software (Fig. 2) for control and data-logging and polarization curves were obtained. All potentials in this work are quoted with respect to $\mathrm{Ag} / \mathrm{AgCl}$ reference electrode. 


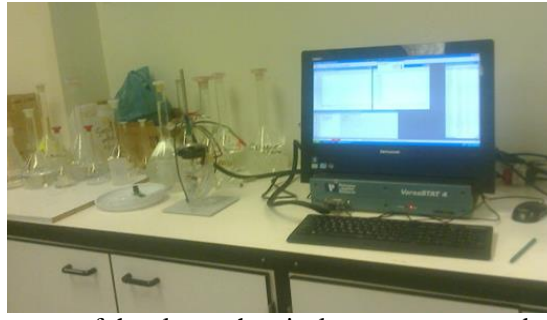

Fig. 2: The set-up of the electrochemical system connected to a personal computer

\section{RESULTS}

\section{A. X-ray diffraction patterns of Anka complex ore}

$\mathrm{X}$ ray diffraction of patterns of size ranges 53, 75, 106 and $150 \mu \mathrm{m}$ (Figure 3) revealed that Anka sulphide ore contains galena, anglesite, sphalerite, magnetite, copper and quartz phases. $150 \mu \mathrm{m}$ shows $84.2 \%$ galena, $8.6 \%$ sphalerite and $9.1 \%$ quartz. $106 \mu \mathrm{m}$ shows $64.3 \%$ galena, $18.9 \%$ sphalerite, $6.6 \%$ quartz and arsenic 9.3\%. while at $75 \mu \mathrm{m}$ anglesite (which is also a lead mineral) was revealed to be $54.6 \%$ copper, $2.02 \%$ sphalerite and $11.1 \%$ Magnetite. Finally, 54.6\% anglesite, $28.3 \%$ galena, $8.8 \%, 4.2 \%$ quartz and $4.4 \%$ were the phases revealed for $53 \mu \mathrm{m}$ respectively. This diffraction pattern shows that the mineral is a complex sulphide ore and need a careful selective separation process to achieve optimum recovery. The minerals are of base metal like lead, zinc, copper and even iron. A good percentage of the valuable minerals were revealed within all the sizes meaning that a good mineral liberation were attained at those particle sizes. Since the behavior of particles in dissolution processes is a function of different properties of the particles including particle sizes, it therefore means that grinding the ore to $53 \mu \mathrm{m}$, will enhance the required concentrate grades with reasonable percentage of valuable minerals to be extracted.

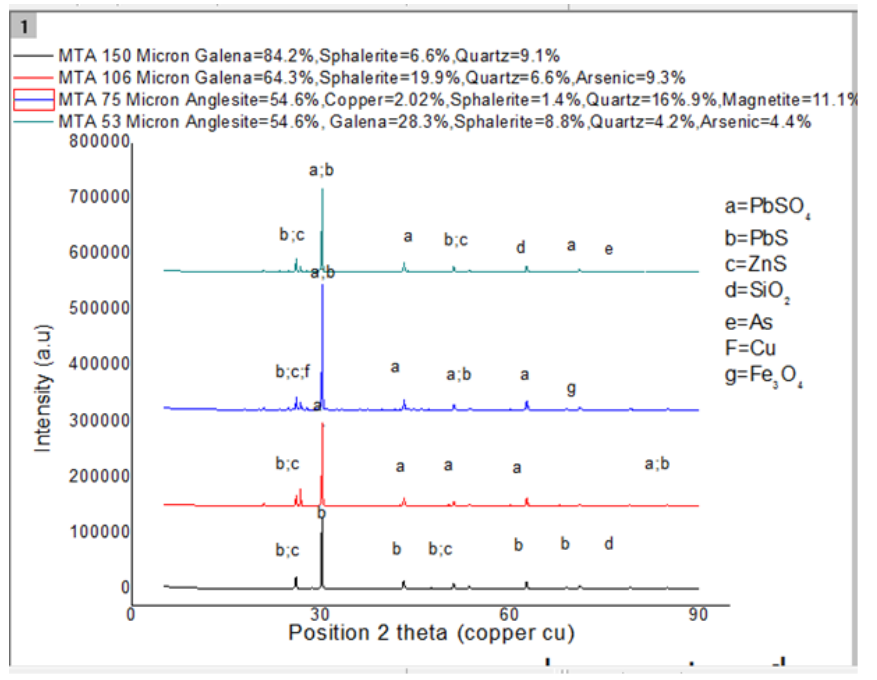

Fig. 3: X-ray diffraction pattern within particle size of Anka sulphide mineral.

\section{B. Morphological analysis of Anka sulphide ore.}

Figure 4 is the SEM Micrograph of Anka complex ore showing the morphological analysis of the deposit. There is presence of $\mathrm{Pb}, \mathrm{Zn}, \mathrm{Fe}, \mathrm{Cu}, \mathrm{S}$ and $\mathrm{Si}$. The morphology of the ores show combination of both large, medium and small sized particles with irregular shapes. The knowledge of morphology has assisted in the study of dissolution of minerals in different media. Dissolution rates of these minerals can be measured by electrochemical process because they can measure low dissolution rates. Gerson and O'Dea, [10] has studied surface species found in galena during oxidation using many techniques. According to (Aydogan, Aras, Ucar and Ertdemoglu 2007), it has been assumed that complexation takes place at the surface of hydrous galena sulphide and that the adsorption of $\mathrm{H}+$ ions onto a surface of the $\mathrm{S}$ atom in the aqueous phase is found to be favourable, whereas the adsorption unto the surface of $\mathrm{Pb}$ atom is not favourable.
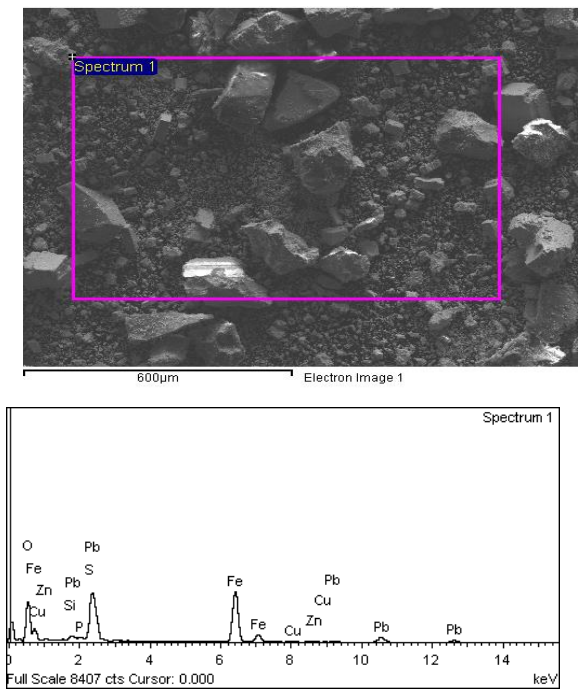

Fig. 4: SEM Micrograph of Anka sulphide mineral

\section{Chemical composition of Anka sulphide ore}

Tables I shows the results of the elemental composition of Anka ore with respect to the total elements present and their distributions within the particle sizes of 53, 75, 106 and $150 \mu \mathrm{m}$ as determined by ICP-OES. It can be seen that the percentage composition of the various elements within the ores vary with difference in particle sizes with variation. Particle size $75 \mu \mathrm{m}$ gave highest weight percentage of $45 \%$ of lead followed by 53 $\mu \mathrm{m}$ which is $44 \% \mu \mathrm{m}$. Meanwhile, particle size $150 \mu \mathrm{m}$ gave is $4.9 \%$ as the highest weight \% of zinc. This means that the deposit is richer in lead than in zinc. There are also other elements at various percentages within the particle sizes. 
TABLE I: ELEMENTAL DISTRIBUTION WITHIN SIZE RANGES OF ANKA

ORE.

\begin{tabular}{llllllllll}
\hline Element & & \multicolumn{2}{c}{$\mathrm{Wt}$ in $\mathrm{mg} / \mathrm{l}$} & \multicolumn{2}{c}{} & & $\mathrm{Na}$ & $\mathrm{Ca}$ \\
& & $\mathrm{Pb}$ & $\mathrm{Zn}$ & $\mathrm{Fe}$ & $\mathrm{Cu}$ & $\mathrm{Si}$ & $\mathrm{S}$ & $\mathrm{Na}$ & \\
\hline Particle size & +150 & 15.0 & 4.9 & 17.0 & 14.0 & 2.0 & 100.0 & 0.42 & 7.5 \\
$(\mu \mathrm{m})$ & $-150+106$ & 20.0 & 3.6 & 5.2 & 17.0 & 2.0 & 75.0 & 0.28 & 3.6 \\
& $-106+75$ & 45.0 & 1.5 & 4.5 & 13.0 & 1.9 & 67.0 & 0.20 & 4.7 \\
& $-75+53$ & 44.0 & 1.5 & 3.5 & 21.0 & 1.6 & 46.0 & 0.16 & 3.5 \\
\hline
\end{tabular}

\section{Open circuit potential for Anka sulphide ore}

Figure 5 shows the graphical representation of open circuit potential for Anka sulphide ore in $1 \mathrm{M} \mathrm{HCl}$ and $\mathrm{H}_{2} \mathrm{O}_{2}$ at varying concentration. There was little or no difference between the reactions of ore in $1 \mathrm{M} \mathrm{HCl}$ plus $0.25,0.5$ and $0.75 \mathrm{M} \mathrm{H}_{2} \mathrm{O}_{2}$. Initial potential $1 \mathrm{M} \mathrm{HCl}$ plus $0.25 \mathrm{M} \mathrm{H}_{2} \mathrm{O}_{2}$ was $0.0 .528 \mathrm{~V}$ which was almost the same compared to when $0.5 \mathrm{M}$ of the oxidant was added and when the oxidant had not been added at all. However, at $0.75 \mathrm{M} \mathrm{H}_{2} \mathrm{O}_{2}$ initial potential was $0.364 \mathrm{~V}$, with addition of $1 \mathrm{M} \mathrm{H}_{2} \mathrm{O}_{2}$ the initial potential was $0.112 \mathrm{~V}$ which gradually decrease to $0.002 \mathrm{~V}$ until it increased to 0.066 by the end of the reaction. This suggests that the $\mathrm{H}_{2} \mathrm{O}_{2}$ has a strong oxidising effect which increased the reaction at the surface electrolyte interface. As concentration of $\mathrm{H}_{2} \mathrm{O}_{2}$ increases, there was increase in the reactivity at the surface electrolyte interface. However, Figure 6 represents effect of varying concentration of $\mathrm{H}_{2} \mathrm{O}_{2}$ plus $1 \mathrm{M} \mathrm{HNO}_{3}$ on the OCP of Anka sulphide ore. The initial OCP was $0.440 \mathrm{~V}$ which kept increasing to $0.523 \mathrm{~V}$ by the end of the reaction period. On adding $\mathrm{H}_{2} \mathrm{O}_{2}$ at varying concentration, the potential decreased with increase in concentration which also signifies that $\mathrm{H}_{2} \mathrm{O}_{2}$ has a strong effect in the surface reactivity of the sulphide ores. Addition of $0.25 \mathrm{M} \mathrm{H}_{2} \mathrm{O}_{2}$ lead to reduced OCP values which means $\mathrm{H}_{2} \mathrm{O}_{2}$ has effect on the reactivity of sulphide mineral in the electrolyte. The surface reactivity between the sulphide mineral and electrolyte at $1,0.25$ and $0.5 \mathrm{M} \mathrm{HNO}_{3}$ plus $\mathrm{H}_{2} \mathrm{O}_{2}$ were very similar and initial potential values are close, $0.440 \mathrm{~V}$, $0.442 \mathrm{~V}$ and $0.403 \mathrm{~V}$ respectively. The reactions were stable all through the period and ended at $0.523 \mathrm{~V}, 0.501 \mathrm{~V}$ and $0.500 \mathrm{~V}$ respectively. Whereas when $0.75 \mathrm{M}$ was added, the potential reduced to $0.386 \mathrm{~V}$ which reduced to $0.350 \mathrm{~V}$ within the first 200 seconds and ended at $0.354 \mathrm{~V}$. On addition of $1 \mathrm{M} \mathrm{H}_{2} \mathrm{O}_{2}$ plus $1 \mathrm{M} \mathrm{HNO}_{3}$, the initial potential was $0.296 \mathrm{~V}$ which reduced drastically within the 300 seconds of the reaction and later increased and kept increasing till the end of the reaction (7200 seconds) at $0.104 \mathrm{~V}$.

\section{E. Electrochemical behaviour of potentiodynamic polarization curves of Anka ore}

Figs. 7 and 8 show the electrochemical behaviour of potentiodynamic polarization curves of Anka sulphide mineral during leaching in $1 \mathrm{M} \mathrm{HNO}_{3}$ and $\mathrm{HCl}$ at varying concentration of $\mathrm{H}_{2} \mathrm{O}_{2}$ respectively. There were slight differences between the behaviour of these samples although some differences were noticed with addition of $\mathrm{H}_{2} \mathrm{O}_{2}$ in varying concentrations. The values of dissolution potentials shifted more negative in both electrolytes with increase in concentration of $\mathrm{H}_{2} \mathrm{O}_{2}$. The dissolution potentials of the mineral in $\mathrm{HCl}$ increased from $0.384 \mathrm{~V}$ in $1 \mathrm{M} \mathrm{HCl}$ to $0.384 \mathrm{~V}, 0.383 \mathrm{~V}$ $0.291 \mathrm{~V}$, and $-0.095 \mathrm{~V}$ in $0.25 \mathrm{M}, 0.5 \mathrm{M}, 0.75 \mathrm{M}$ and $1 \mathrm{M} \mathrm{H}_{2} \mathrm{O}_{2}$, respectively. Meanwhile, in $1 \mathrm{M} \mathrm{HNO}_{3}$ it shifted from -0.5498 $\mathrm{V}$ to $0.5498 \mathrm{~V}, 0.5498 \mathrm{~V}, 0.3252 \mathrm{~V}$, and $0.0996 \mathrm{~V}$ on adding $0.25 \mathrm{M}, 0.5 \mathrm{M}, 0.75 \mathrm{M}$ and $1 \mathrm{M} \mathrm{H}_{2} \mathrm{O}_{2}$ respectively.

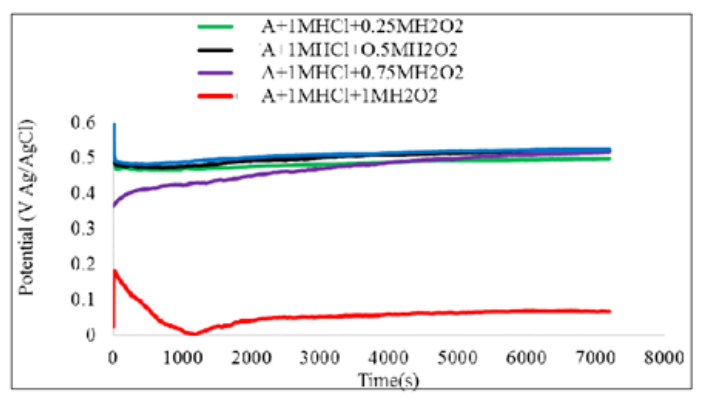

Fig. 5: Effect of varying concentration of $\mathrm{H}_{2} \mathrm{O}_{2}$ plus $1 \mathrm{M} \mathrm{HCl}$ on the OCP of Anka sulphide mineral.

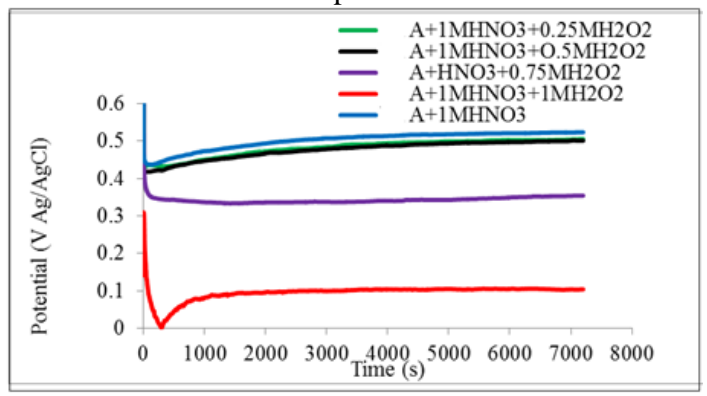

Fig. 6: Effect of varying concentration of $\mathrm{H}_{2} \mathrm{O}_{2}$ plus $1 \mathrm{M} \mathrm{HNO}_{3}$ on the $\mathrm{OCP}$ of Anka sulphide mineral.

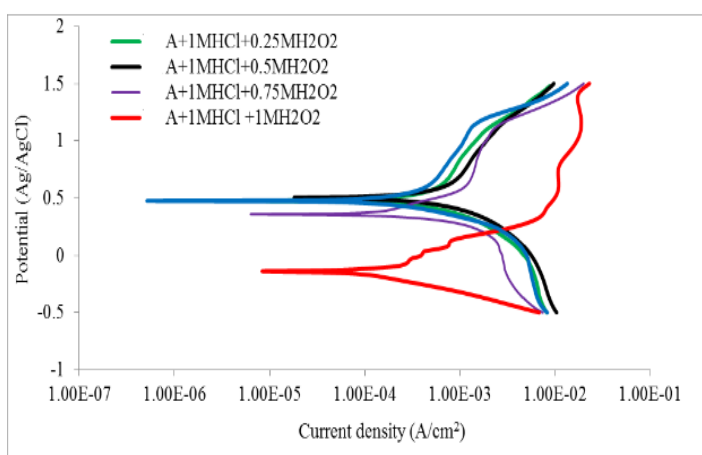

Fig. 7: Electrochemical behaviour of potentiodynamic polarization curves of Anka sulphide mineral in $\mathrm{HCl}$ 


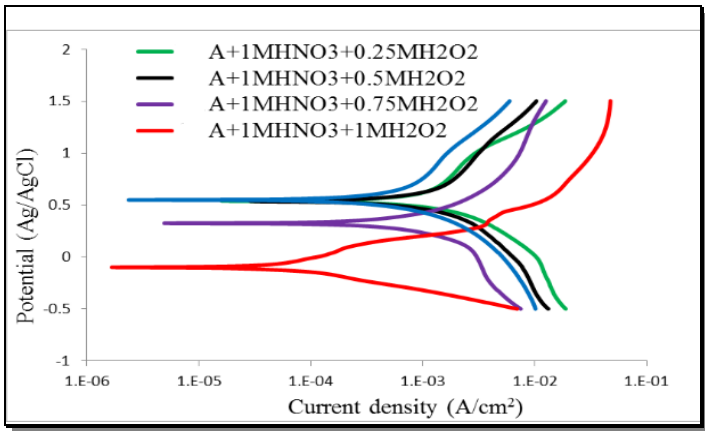

Fig. 8: Electrochemical behaviour of potentiodynamic polarization curves of Anka sulphide mineral in HNO3

\section{F. Chronoamperometric behaviour of Anka sulphide ore}

Figs. 9 and 10 show the Chronoamperometric curves of Anka sulphide mineral under the different applied potentials of $0.6,0.8,1.0$ and $1.2 \mathrm{~V}$. These applied potentials were selected at the region of passivation on the polarization curves that were shown in Figs. 6 and 7. The concentration of the electrolyte selected for the all chronoamperometric tests was $1 \mathrm{M} \mathrm{HCl}$ $+0.25 \mathrm{M} \mathrm{H}_{2} \mathrm{O}_{2}$ and $1 \mathrm{M} \mathrm{HNO}_{3}+0.25 \mathrm{M} \mathrm{H}_{2} \mathrm{O}_{2}$. Dissolution current decreased with increase in time for both reactions. $1 \mathrm{M}$ $\mathrm{HCl}+0.25 \mathrm{M} \mathrm{H}_{2} \mathrm{O}_{2}$ shows highest dissolution kinetics at $0.8 \mathrm{~V}$ applied potential (Figure 8) while initial current was 0.0181 $\mathrm{A} / \mathrm{cm}^{2}$ but within the first 240 seconds, it had reduced to about $0.0069 \mathrm{~A} / \mathrm{cm}^{2}$ and kept reducing gradually till it came to 0.0015 $\mathrm{A} / \mathrm{cm}^{2}$ by 7200 seconds which was the period of the reaction. This means that there was a rapid rate of reaction at electrode interface which became reduced with time. The reaction at electrode interface were almost similar when potentials $1.0 \mathrm{~V}$ and $1.2 \mathrm{~V}$ were applied and the dissolution currents were lower than that of $0.8 \mathrm{~V}$. The least of the reactions was observed at 0.6 $\mathrm{V}$ applied potential. However, as the time was increasing, the reaction current were also increasing. The trend of reactions of in $\mathrm{HNO}_{3}$ was different because for $1 \mathrm{M} \mathrm{HNO}_{3}+0.25 \mathrm{M} \mathrm{H}_{2} \mathrm{O}_{2}$ highest dissolution occurred at $1.2 \mathrm{~V}$, followed by $1.0,0.8$ and $0.6 \mathrm{~V}$ respectively as shown in Figure 8. Values of dissolution current at 1.2, 1.0, 0.8 and $0.6 \mathrm{~V}$ were $0.0026 \mathrm{~A} / \mathrm{cm}^{2}, 0.0015$ $\mathrm{A} / \mathrm{cm}^{2}, 0.000724 \mathrm{~A} / \mathrm{cm}^{2}$ and $0.00032 \mathrm{~A} / \mathrm{cm}^{2}$ respectively. Meanwhile, slight current fluctuations observed can be attributed to simultaneous dissolution and passivation of concentrates at the electrolyte-particle interface. [18], also reported Force fluctuation as expected following a random mechanical interaction between colliding asperities.

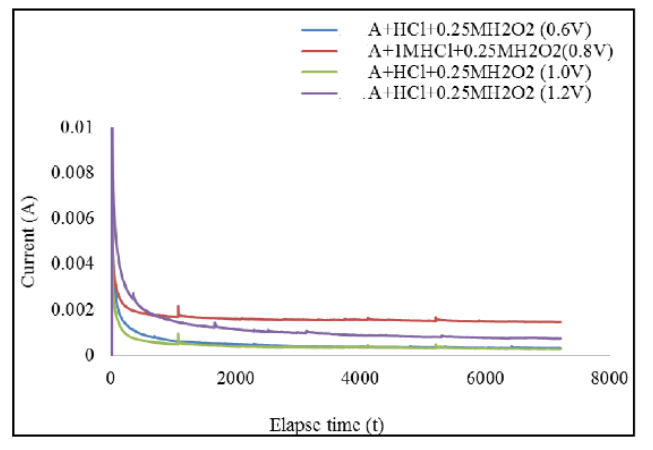

Fig. 9: Chronoamperometric curves of Anka sulphide mineral in $\mathrm{HCl}+\mathrm{H} 2 \mathrm{O} 2$

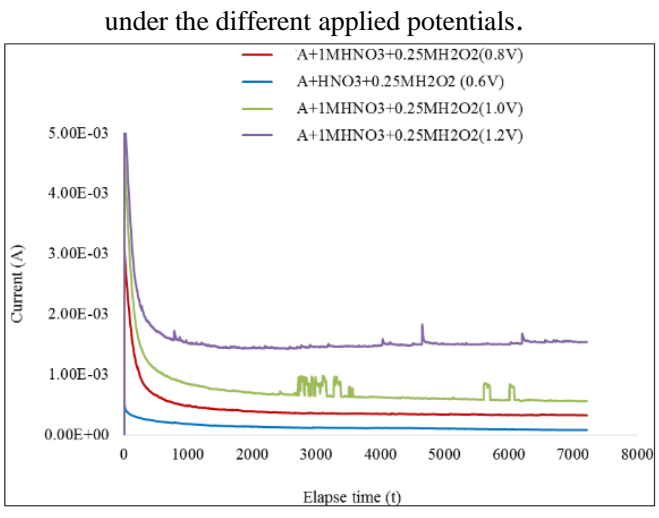

Figure 10: Chronoamperometric curves of Anka sulphide mineral $\mathrm{HCl}+\mathrm{H}_{2} \mathrm{O}_{2}$ under the different applied potentials.

TABLE II: DISSOLUTION DATA OBTAINED FROM THE ELECTROCHEMICAL TESTS PERFORMED ON ANKA SULPHIDE ORE IN $1 \mathrm{M}$ HCL+ $\mathrm{H}_{2} \mathrm{O}_{2}$ AT VARYING MOLARITY.

\begin{tabular}{lllll}
\hline $\begin{array}{l}\text { Molarity of } \\
\mathrm{HCl}(\mathrm{M})\end{array}$ & $\begin{array}{l}\text { Molarity of } \\
\mathrm{H} \mathrm{O}_{2}(\mathrm{M})\end{array}$ & $\frac{\text { Icorr }\left(\mathrm{A} / \mathrm{cm}^{2}\right)}{4.53 \mathrm{E}-05}$ & $\frac{2}{2.92 \mathrm{E}-01}$ & $\begin{array}{l}\text { Ecorr }(\mathrm{V}) \\
\text { rate }(\mathrm{mm} / \mathrm{yr})\end{array}$ \\
\hline 1 & 1 & $2.08 \mathrm{E}-05$ & $3.81 \mathrm{E}-01$ & $6.21 \mathrm{E}-01$ \\
1 & 0.75 & $9.93 \mathrm{E}-06$ & $3.60 \mathrm{E}-01$ & $1.36 \mathrm{E}-01$ \\
1 & 0.5 & $4.85 \mathrm{E}-06$ & $3.35 \mathrm{E}-01$ & $6.65 \mathrm{E}-02$ \\
1 & 0.25 & $2.99 \mathrm{E}-06$ & $3.31 \mathrm{E}-01$ & $3.494-3$ \\
1 & None & & & \\
\hline
\end{tabular}

Tables II and III presents dissolution data obtained from the electrochemical tests performed on Anka sulphide ore in $1 \mathrm{M}$ $\mathrm{HCl}+\mathrm{H}_{2} \mathrm{O}_{2}$ and $1 \mathrm{MHO}_{3}+\mathrm{H}_{2} \mathrm{O}_{2}$ at varying molarity. The dissolution current density, Icorr $\left(\mathrm{A} / \mathrm{cm}^{2}\right)$, dissolution potential, Ecorr (V) and the dissolution rate $(\mathrm{mm} / \mathrm{yr})$ are presented. Corrosion (dissolution) potential Ecorr (V) gives the information of dissolution tendency only the dissolution rate is proportional to the current density. The dissolution rate is automatically calculated from the current density. Highest dissolution rate (6.21E-01) for $\mathrm{HCl}$ was recorded at $1 \mathrm{M} \mathrm{HCl}+1 \mathrm{M} \mathrm{H}_{2} \mathrm{O}_{2}$ while that of $\mathrm{HNO}_{3}(1.06 \mathrm{E}+00)$ was also recorded at $1 \mathrm{M} \mathrm{HNO}_{3}+1 \mathrm{M}$ $\mathrm{H}_{2} \mathrm{O}_{2}$. This means that dissolution is higher in $\mathrm{HNO}_{3}$ than $\mathrm{HCl}$. 
TABLE III: DisSOlUTION DATA OBTAINED FROM THE ELECTROCHEMICAL TESTS PERFORMED ON ANKA SULPHIDE ORE IN $1 \mathrm{M} \mathrm{HNO}_{3}+\mathrm{H}_{2} \mathrm{O}_{2}$ AT VARYING MOLARITY

\begin{tabular}{lllll}
\hline $\begin{array}{l}\mathrm{Molarity} \text { of } \\
\mathrm{HNO}_{3}(\mathrm{M})\end{array}$ & $\begin{array}{l}\text { Molarity of } \\
\mathrm{H}_{2} \mathrm{O}_{2}(\mathrm{M})\end{array}$ & $\frac{\text { Icorr }\left(\mathrm{A} / \mathrm{cm}^{2}\right)}{7.75 \mathrm{E}-05}$ & $\frac{\text { Ecorr }(\mathrm{V})}{4.64 \mathrm{E}-01}$ & $\begin{array}{l}\text { Dissolution } \\
\text { rate }(\mathrm{mm} / \mathrm{yr})\end{array}$ \\
\hline 1 & 1 & $6.80 \mathrm{E}-05$ & $3.27 \mathrm{E}-01$ & $1.06 \mathrm{E}+00$ \\
1 & 0.75 & $5.034-5$ & $5.34 \mathrm{E}-01$ & $6.318-01$ \\
1 & 0.5 & $3.87 \mathrm{E}+00$ & $5.37 \mathrm{E}-01$ & $5.902-01$ \\
1 & 0.25 & $2.51 \mathrm{E}-05$ & $5.36 \mathrm{E}-01$ & $3.44 \mathrm{E}-01$ \\
1 & None & & & \\
\hline
\end{tabular}

\section{CONCLUSION}

Comparative effects of acidified hydrogen peroxide on dissolution behaviour of Anka complex sulphide mineral for advanced materials application. The electrolytes used were $\mathrm{HCl}$ and $\mathrm{HNO}_{3}$ plus $\mathrm{H}_{2} \mathrm{O}_{2}$. Open circuit potential, potentiodynamic polarization and Chronoamperometric methods were electrochemical methods were applied in this investigation. Mineralogical analysis revealed that the mineral contain some base metals $(\mathrm{Pb}, \mathrm{Zn}, \mathrm{Fe}$, and $\mathrm{Cu})$ which can be extracted for engineering purposes. It was discovered that addition of $\mathrm{H}_{2} \mathrm{O}_{2}$ enhances dissolution of Anka complex sulphide ore and optimum dissolution rate were obtained with $1 \mathrm{M} \mathrm{HNO}_{3}+1 \mathrm{M}$ $\mathrm{H}_{2} \mathrm{O}_{2}$. Potentiodynamic polarization curves show that behaviour of the mineral with $\mathrm{HCl}$ and $\mathrm{HNO}_{3}$ plus $\mathrm{H}_{2} \mathrm{O}_{2}$ were similar in the sense that dissolution potentials shifted negatively as concentration of $\mathrm{H}_{2} \mathrm{O}_{2}$ increases from $0.25 \mathrm{M}$ to 1 M. Chronoamperometric behaviour of the mineral show that dissolution kinetics decrease with increase in time up to 7200 seconds for the various applied potentials [19]. The dissolution data obtained from electrochemical tests show that the presence of hydrogen peroxide enhance dissolution with $\mathrm{HCl}$ and $\mathrm{HNO}_{3}$; dissolution rates increase with increase in molarity of $\mathrm{H}_{2} \mathrm{O}_{2}$ (up to $1 \mathrm{M}$ ) plus $1 \mathrm{M} \mathrm{HCl}$ and $\mathrm{HNO}_{3}$ Respectively. Highest dissolution rate of $1.066+00 \mathrm{~mm} / \mathrm{yr}$ was obtained from $\mathrm{HNO}_{3}$ plus I $\mathrm{M} \mathrm{H}_{2} \mathrm{O}_{2}$. Nitric acid has higher tendency to dissolve Anka sulphide ore than hydrochloric acid especially when it is added to hydrogen peroxide. It has been ascertained that hydrogen peroxide and nitric acid solutions have considerable positive effects on the dissolution of Sphalerite ores [20].

\section{REFERENCES}

[1] N. Terry and J. Sharif, "Low grade ores smelt leach or concentrate?," Mineral Engineering, vol. 23, no. 2, pp. 65-73, 2010. https://doi.org/10.1016/j.mineng.2009.10.002

[2] F. K. Crundwell, "The mechanism of dissolution of minerals in acidic and alkaline solutions: Part III. Application to oxide, hydroxide and sulfide minerals," Hydrometallurgy, vol. 149, pp. 71-81, 2014. https://doi.org/10.1016/j.hydromet.2014.06.008

[3] K. H. Rao and I. V. Chernyshova, "Study of challenges in sulphide mineral processing," The Open Mineral Processing Journal, vol. 4, pp. 7-13, 2011. https://doi.org/10.2174/18748414001104010007

[4] P. R. Holmes, F. K. Crundwell, "Kinetics Aspect of Galvanic Interactions between Minerals during Dissolution," Hydrometallurgy, vol. 39, pp. 353-375, 1990. https://doi.org/10.1016/0304-386X(95)00041-E

[5] A. F. Tshilombo, D. G., Dixon Kinetics Study of Chalcopyrite and Passivation during Electrochemical and Chemical Leaching. Electrochemical society Proceedings, 18: 108, 2003.
[6] Z. Y. Lu, M. I. Jeffrey,.and F. Lawson,. "An Electrochemical Study of the Effect of Chloride Ions on the Dissolution of Chalcopyrite in Acidic Solutions," Hydrometallurgy, vol. 56, pp. 145-155, 2000. https://doi.org/10.1016/S0304-386X(00)00068-2

[7] O. O. Ola-Omole, P. A Olubambi., B. O. Adewuyi, and , J. O. Borode, Electrochemical Studies of Dissolution Behaviour of Ishiagu Sulphide Ore Proceedings of the Annual Conference of School of Engineering and Engineering Technology, Federal University of Technology Akure. 917-927, 2018.

[8] H. Koohestani, E.S. Khatami and K. Babaei, "Comparative investigation of leaching of zinc from wastes of the zinc alloy production process," Mineral Processing and Extractive Metallurgy, pp.1-7. 2019. https://doi.org/10.1080/25726641.2019.1660506

[9] E. Arce, and I. Gonzalez, "A comparative study of electrochemical behaviour of chalcopyrite, chalcocite and bornite in sulphuric acid solution," International journal of mineral processing. vol 67, pp. 17-28, 2002.

https://doi.org/10.1016/S0301-7516(02)00003-0

[10] A.R. Gerson, and A.R. O'Dea, "A quantum chemical investigation of the oxidation and dissolution mechanisms of Galena", Geochimica et Cosmochimica Acta, vol. 67, no. 5, pp. 813-822, 2003. https://doi.org/10.1016/S0016-7037(02)01147-X

[11] S. Aydogan, A. Aras, G. Ucar, and M. Ertdemoglu, "Dissolution kinetics of galena in acetic acid solutions with hydrogen peroxide," Hydrometallurgy vol. 89, pp. 189-195, 2007. https://doi.org/10.1016/j.hydromet.2007.07.004

[12] N.G Picazo-Rodríguez, M. Soria-Aguilar, A. Martínez-Luévanos, I. Almaguer-Guzmán, J. Chaidez-Félix, and F.R. Carrillo-Pedroza, "Direct Acid Leaching of Sphalerite: An Approach Comparative and Kinetics Analysis", Minerals, vol. 10, no 4, pp.359, 2020. https://doi.org/10.3390/min10040359

[13] A. A. Baba and F. Adekola, "A Study of Dissolution Kinetics of a Nigerian Galena Ore in Hydrochloric Acid," Journal of Saudi Chemical Society, vol. 16, pp. 377-386, 2011. https://doi.org/10.1016/j.jscs.2011.02.005

[14] J. Zuo-mei, G.W. Warren, and H. Henein, "Reaction Kinetics of Ferric Chloride Leaching of Sphalerite: An Experimental Study," Metallurgical Transaction. B. vol. 15B, pp. 5-12, 1984. https://doi.org/10.1007/BF02661056

[15] P.A. Olubambi, J.O. Borode, and S. Ndlovu, "Sulphuric acid leaching of zinc and copper from Nigerian Complex Sulphide Ore in the presence of hydrogen peroxide", The Journal of The Southern African Institute of Mining and Metallurgy, vol. 106, pp. 765-770, 2006.

[16] N.M. Waziri, and J.E Andrews, "In vitro bioaccessibility of lead in Artisanal mining contaminated soils and sediments from the Anka area, NW Nigeria," Earth Science Research, vol. 3, no. 1, pp. 1, 2014. https://doi.org/10.5539/esr.v3n1p1

[17] M. R. Ali, R. B. Kumar, and M.Z.A. Golam, "Study on the Electrochemical Dissolution of Ilmenite Fraction of Beach Sand in Sulphuric Acid Solution", International Conference on Materials, Electronics \& Information Engineering, pp. 05-06, 2015.

[18] X. Li, K. Tang, and M. Tangstad, "Reduction and Dissolution Behaviour of Manganese Slag in the Ferromanganese Process," Minerals, vol. 10, no. 2, pp. $97-22,2020$. https://doi.org/10.3390/min 10020097

[19] O. Ozdemir, M.A. Hampton, T.A. Nguyen, and A. Nguyen, "Difference in flotation behavior of galena by single and multi-step chronoamperometric oxidation," Physicochemical Problems of Mineral Processing; vol. 55 no. 3, pp. 812-821, 2019.

[20] A.O. Adebayo, A., K.O. Ipinmoroti and O.O Ajayi, "Leaching of Sphalerite with Hydrogen Peroxide and Nitric Acid," Journal of Minerals and Materials Characterization and Engineering, vol. 5, no. 2, pp. 167-77, 2006.

https://doi.org/10.4236/jmmce.2006.52012 